\title{
INTERDISCIPLINARY COOPERATION IN PREVENTIVE PROCEDURES OF OSTEONECROSIS OF THE JAW BONE IN PATIENTS TREATED WITH BISPHOSPHONATES
}

\author{
Eva Koval'ová, Tatiana Klamárová, Anna Eliašová, Bohuslav Novák \\ Faculty of Health, Presov University, Slovakia \\ Dental Clinic OUSA, Bratislava
}

Koval'ová E., Klamárová T., Eliašová A., Novák B. (2015), Interdisciplinary cooperation in preventive procedures of osteonecrosis of the jaw bone in patients treated with bisphosphonates. Health Problems of Civilization, 4 (9), p. 49-53.

Summary: Objective: The authors submitted a proposal of preventive procedures to eliminate the risks of osteonecrosis of the jaw bone in patients treated with bisphosphonates using interdisciplinary cooperation of specialists. Conclusion: Before starting the treatment of bone metastases with bisphosphonates, all patients should have dental examination, dental treatment and dental hygiene treatment as a prevention of osteonecrosis of the jaw bone. The application of preventive approaches can reduce risk and eliminate the incidence of osteonecrosis of the jaw in patients who have to take bisphosphonates.

Keywords: bisphosphonates, osteonecrosis of the jaw bone, risk patients in dental hygiene

\section{Introduction}

Bisphosphonates are agents commonly used in the treatment of bone diseases in case of multiple myeloma, of hypercalcaemia and skeletal metastases which can appear as a consequence of breast, lung or prostate carcinoma (Pour et al. 2007). These drugs are able to stop the development of new skeletal metastases. They alleviate the pain, reduce the risk of bone fracture and of overpressure of the spinal cord in case of vertebras malignancy (Jarolim 2005).

The most prescribed bisphosphonates in our country are: Zometa, Bonefos, Aredia, Pamitor and Sindronat (Poršová et al. 2007). A serious complication can occur during the dentist's treatment of patients using Bisphosphonates - ONJ or osteonecrosis of the jaw. The most common symptom is a non-healing jaw-wound (Machalka et al. 2006). A doctor and a dentist who prescribes bisphosphonates should know the risks that can cause ONJ-development: tooth extraction or another surgical intervention during or after the bisphosphonate therapy, poor oral hygiene, osteoporosis, bad oral conditions, non-fitting denture or oral metastasis.

\section{Osteonecrosis of the jaw bone in patients treated with bisphosphonates}

The ONJ is described as a mucosa wound with open bone or as a non-healing extraction wound (Picture 1). Other symptoms are inflammations, pain, foetor ex ore, fistula or an x-ray which shows the non-healing bone after tooth extraction or another surgical intervention (Picture 2,3). Less common symptoms are the lack of the mucosa wound, gingival diseases, high sensitivity of the tooth, the lack of the pain and of the inflammation in the area of the necrotic bone and the mucosa wound. But the existence of these symptoms does not automatically implicate ONJ (Jordán et al. 2010). We could find the osteonecrosis in the upper jaw in 28\% of the patients, in $68 \%$ in mandibula and in $4 \%$ of all cases were both jaws affected.

\footnotetext{
Address for correspondence: Eva Kovalova, University of Presov, Faculty of Health, Parizanska 1, 080 01 Presov, Slovakia, tel.: 00421908 9747 03, e-mail: kovalova@nextra.sk

Tables: 0 Figures: 5 References: 12 Full-text PDF www.hpc.edu.pl Copyright (C) Pope John Paul II State School of Higher Education in Biała Podlaska, Sidorska 95/97, 21-500 Biała Podlaska Indexation: Index Copernicus, AGR0, ProQuest, Polish Medical Bibliography, Polish Ministry of Science and Higher Education. This is an open-access article distributed under the terms of the Creative Common Attribution Non-commercial license (http://creativecommons.org/licenses/by-nc/3.0), which permits use, distribution and reproduction in any medium, provided the original works is properly cited, the use is non-commercial and is otherwise in compliance with the license.
} 


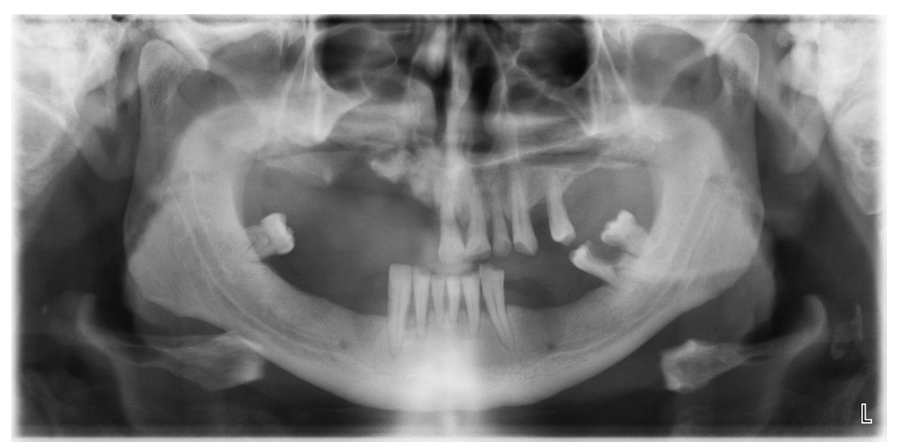

Picture 1. X-ray of a patient with bisphosphonate therapy

A non-healing wound in regio 13 - 17. Status 3 months after the extraction.
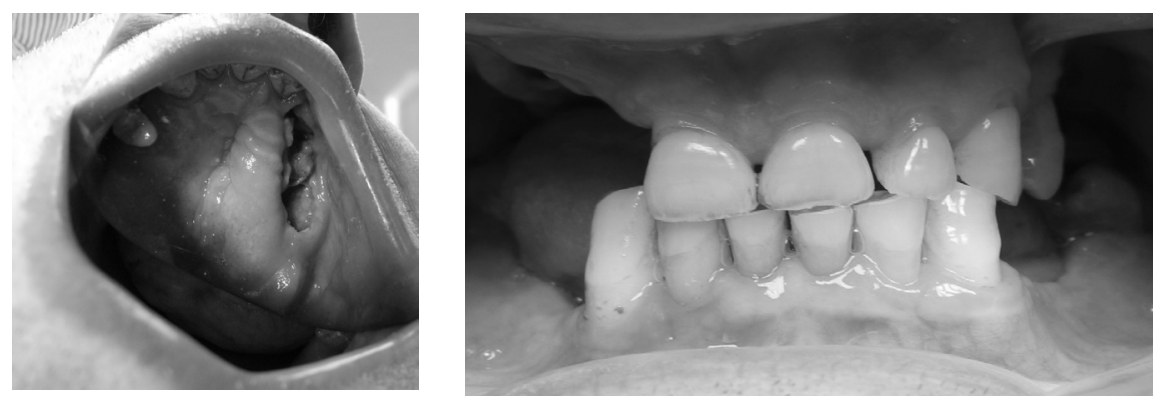

Picture 2, 3. Bisphosphonate associated osteonecrosis in the upper jaw The cause was an instable denture.

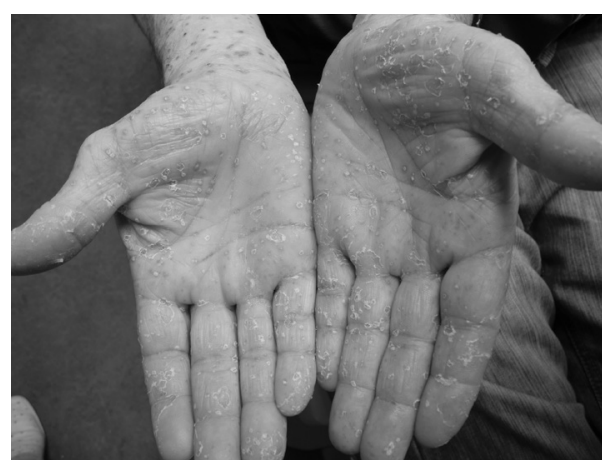

Picture 4. Bisphosphonate associated implications in the skin

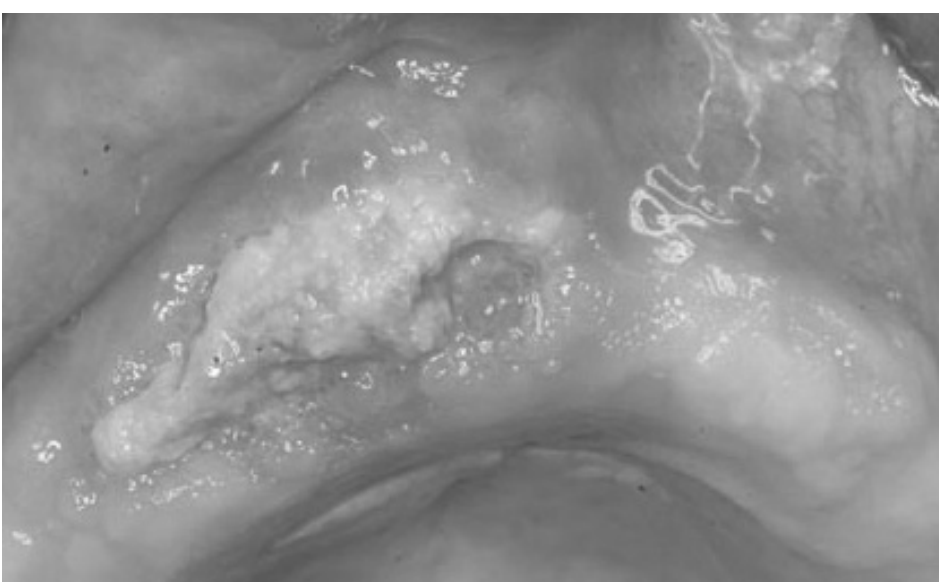

Picture 5. Bisphosphonate associated osteonecrosis in the lower jaw The cause was an instable denture. 


\section{Discussion}

Bisphosphonates play a major role in the prophylaxis and the therapy of bone metastases. Bisphosphonates are chemically stable analogues of inorganic pyrophosphate that are able to resist hydrolysis. Pyrosphosphate can be found in the bone matrix (Matoušková, Hanuš 2009).

By the blood circulation system, Bisphosphonates are delivered to the bone areas with the highest resorption. The most important function of bisphosphonates is to stop or to reduce this resorption. They have a high affinity to calcium (bone surface and free $\mathrm{Ca}$ ). The reduction of bone resorption is managed by the bisphosphonates by reducing the activity of osteoclasts. Bisphosphonates interfere cell mechanism of osteoclasts and induce their apoptosis. As a consequence, they are able to reduce the amount of osteoclasts. More over, bisphosphonates reduce the amount of cytokines and the growth factors that have an influence on the bone resorption. Due to these abilities, the bisphosphonates stop the circuit of bone destruction (Saad 2004).

There are two ways bisphosphonates can be taken - oral application and i.v. application. Bisphosphonates taken orally don't have such a strong bone effect as bisphosphonates that are i.v. applicated. Only $1 \%$ of orally applicated bisphosphonates are being resorbed. Highly effective are i.v. applicated bisphosphonates that content nitrogen (e.g. zoledronic acid). These bisphosphonates are commonly prescribed to patients with prostate carcinoma to prevent or reduce the bone metastases. They are able to reduce and postpone the beginning of bone complications for about 5 months. At all, they reduce the risk of bone complications by $36 \%$. The suppression of angiogenesis is also very significant effect of bisphosphonates.

The studies showed that the pain reducing effect was $11 \%$ higher in the test group where zoledronic acid was applicated than in a control placebo group (Tesař, Tesařová 2008).

The therapy with bisphosphonates is recommended for patients with skeletal metastases before the pain occurs. As a consequence, the therapy with analgesics can be postponed. The most common side effect during the therapy with bisphosphonates is a flu-like syndrome (15-20\% of patients). Another very serious side effect is an osteonecrosis of the jaw.

It can be found in upper and lower jaw of patients, no matter if bisphosphonates are orally or i.v. applicated. Mostly concerned were patients with multiple myeloma and breast carcinoma (Vít 2009). Possible causes are tooth extraction, oral infection, exostosis, injury of the mucosa for example by denture and poor oral hygiene. There are also risk factors like radiotherapy, corticoids, cytostatic drugs etc. which can influence the formation of osteonecrosis. Before beginning the therapy with bisphosphonates, it is very important to give a complete oral treatment in order to prevent any surgical intervention during this therapy. The therapy of osteonecrosis is mostly conservative with the help of antibiotics but in serious cases a surgical intervention has to be done (Jordán et al. 2010). If a so called „drug-holiday“(interruption of bisphosphonate therapy) is advisable, hasn't yet been fully clarified. It is very important to deliberate about whether a carcinoma patient should waive the great effects of e.g. zoledronic acid because of osteonecrosis (Neville-Webbe, Coleman 2010).

The authors are proposing a preventive program for patients who are about to get a bisphosphonate therapy. This program should be known to:

1. Bisphosphonates prescribing specialists

2. Patients treated with bisphosphonates

3. Dentists and dental hygienist who treat patients taking bisphosphonates

\section{A. Before the beginning of bisphosphonate therapy}

A/1. The oncologist, hematologist, urologist, gynecologist, orthopedist and other specialists who are about to prescribe bisphosphonates should refer the patient to a dentist for a complete check-up.

A/2. The patient should be informed about bisphosphonates by a doctor and with the help of brochures. The patient should know that a good oral hygiene reduces the risk of the creation of osteonecrosis. He should also inform the dentist about getting the bisphosphonate therapy and visit the dentist for a check-up min. twice a year.

\section{A/3. The dentist and dental hygienist:}

a. Should inform the patient about the importance of a check-up and about an oral treatment (if necessary) before the beginning of a bisphosphonate therapy in order to prevent complications during the therapy.

b. Should make a complete check-up inclusive x-ray, treat the patient (if necessary) and make a recall-program for the patient.

c. Should give a professional oral hygiene and explain to the patient the importance of a good oral hygiene at home. The disinfection with the help of a mouthwash (with chlorhexidine $0,12 \%$ ) 
should be recommended (for 14 days, once per 3 months).

d. Should control all the prostheses. Instable denture can cause an injury of the mucosa which may cause an osteonecrosis. All inaccurate prostheses should be corrected.

e. Should extract all destroyed teeth (rest radix, teeth with big secondary caries, dead teeth, teeth with inexact root canal filling etc.). These teeth can be the source of a focal infection. Especially non-motivable patients with poor oral hygiene should be treated thoroughly. An extraction during the bisphosphonate therapy is a big risk of the creation of an osteonecrosis. The goal of these precautionary measures is to reduce the number of extractions during the bisphosphonate therapy.

\section{B. During the bisphosphonate therapy without any complications}

B/1. The specialist should inform the patient about the risks of the therapy and about the precautions. The patient should be referred to a dentist for a complete check-up.

B/2. The patient -like in $\mathrm{A} / 2$.

B/3. The dentist, dental hygienist -like in A/3 a-d. If it is necessary to extract a tooth, the dentist should refer the patient to a maxillofacial surgery clinic.

\section{During the bisphosphonate therapy with complications and bisphosphonate osteonecrosis}

C/1. The specialist should inform the patient about risks of the therapy and about the possible treatment of the complications. The patient should be referred to a dentist.

$\mathrm{C} / 2$. The patient -like in $\mathrm{B} / 2$.

C/3. The dentist, dental hygienist should give a complete check-up and a professional oral hygiene like in $\mathrm{A} / 3 \mathrm{a}$-d. If it is necessary to extract a tooth or if an osteonecrosis is found, the dentist, dental hygienist should refer the patient to a maxillofacial surgery clinic. If a surgical intervention is necessary, it should be done very circumspectly and the wound should be sutured with a special multilayer closure. The antibiotics should be given (amoxicillin/clavulanic acid, clindamycin, spiramycin) and the mouth should be disinfected with chlorhexidine $0,2 \%$ for 14 days twice a day. The sutures should be removed 2 weeks after the intervention and the patient should keep on rinsing the mouth with chlorhexidine $0,12 \%$.

\section{Conclusion}

If a bisphosphonate therapy has been planed, precautionary measures like check-up and complete treatment are very important. All destroyed teeth should be extracted to prevent an osteonecrosis. The authors are proposing a preventive program where the cooperation between a specialist, a dentist, a dental hygienist and the patient plays a key role (Koval' 2009, Koval' 2010). The precautionary measures mentioned in this article should also be involved in biological therapy of rheumatism, transplantations etc. The studies have already shown that a preventive program concerning the therapy with bisphosphonates can avoid complications like osteonecrosis of the jaw.

\section{Anamnesis}

Please answer the questions! Please inform us about every change since the last appointment!

\begin{tabular}{|c|c|}
\hline 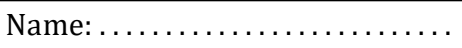 & Date of birth: ............. \\
\hline Address: . . . . . . . . . . . . . . & Profession: .............. \\
\hline Tel.No.: .................... & Tel.No. at work:............ \\
\hline Referred by: ............. & \\
\hline
\end{tabular}

\begin{tabular}{lccl} 
& & \\
& Yes & No & \multicolumn{1}{c}{ Women: } \\
Have you been to the hospital during the last year? & $\square$ & $\square$ & Are you pregnant? \\
Do you smoke? & $\square$ & $\square$ & Do you breast-feed? \\
Are you allergic to something? & $\square$ & $\square$ & Do you take contraceptive pills? \\
Do you have bad blood coagulation? & $\square$ & $\square$ & $\square$
\end{tabular}




\begin{tabular}{|c|c|c|c|c|c|}
\hline \multicolumn{6}{|c|}{ Do you have or have you ever had: } \\
\hline & Yes & No & & Yes & No \\
\hline High blood pressure? & $\square$ & $\square$ & Any implant or artificial joint? & $\square$ & $\square$ \\
\hline Anticoagulants? & $\square$ & $\square$ & Asthma? & $\square$ & $\square$ \\
\hline Heart problems? & $\square$ & $\square$ & Anemia? & $\square$ & $\square$ \\
\hline Heart attack? & $\square$ & $\square$ & Leukemia? & $\square$ & $\square$ \\
\hline Heart murmur? & $\square$ & $\square$ & Diabetes? & $\square$ & $\square$ \\
\hline Cardiac stimulator? & $\square$ & $\square$ & Tumor? & $\square$ & $\square$ \\
\hline Chest pain? & $\square$ & $\square$ & Radiotherapy/Chemotherapy? & $\square$ & $\square$ \\
\hline Apoplexy? & $\square$ & $\square$ & Problems with thyroid gland? & $\square$ & $\square$ \\
\hline Epilepsy? & $\square$ & $\square$ & Hepatitis $(A, B, C) ?$ & $\square$ & $\square$ \\
\hline Sickness? & $\square$ & $\square$ & Liver or kidney problems? & $\square$ & $\square$ \\
\hline Rheumatic fever? & $\square$ & $\square$ & Any transplantation? & $\square$ & $\square$ \\
\hline Arthritis? & $\square$ & $\square$ & AIDS (HIV) & $\square$ & $\square$ \\
\hline Rheumatism? & $\square$ & $\square$ & Venereal disease? & $\square$ & $\square$ \\
\hline Skin illnesses? & $\square$ & $\square$ & Neurologic disease? & $\square$ & $\square$ \\
\hline
\end{tabular}

Are you in therapy? :

osteoporosis, prostate carcinoma, breast carcinoma. Do you take medicine- bisphosphonates?

Do you visit your dentist or dental hygienist regularly, min. once per year?

Other illnesses, problems or complications:

Date:

Signature:

The most common biphosphonates: ZOMETA, Bondronat, Aredia, Pamifos, Actonel, Aclasta, Fosamax, Bonviva, Bonefos, Alendron, Tevanate, Clodron, Ostac, Didronel, Diphos, Etidron, Etidronat, Skelid, Pamidrocell, Pamidron-Hexal, Ribodronat

\section{References:}

1. Jarolim L. (2005), Trendy systémové léčby karcinómu prostaty. Urolog. pro Praxi, 2: 62-65.

2. Jordán D., Fedurcová I., Lenzová L. (2010), Právne následky pri porušení kompetencií v zubnej ambulancii. Recenzovaný zborník, Medzinárodný týždeň dentálnej hygieny, FZ PU v Prešove.

3. Koval' A. (2009), Etický kódex a marketingová prax. Prešov: Fakulta manažmentu PU v Prešove, 73 s. Diplomová práca.

4. Koval' A. (2010), Hodnotový manažment vybranej skupiny zdravotníckych pracovníkov a ich klientov. Fakulta manažmentu PU v Prešove, Rigorózna práca.

5. Machalka M., Adam Z., Bulik O. (2006), Osteonekróza čelisti při léčbě bisfosfonáty. Český stomatológ., (106) 5: 136-139.

6. Matoušková M., Hanuš M. (2009), Bisfosfonáty v léčbě kostních metastáz v urologii. Urolog. pro Praxi, (10) 5: 282-286.

7. Neville-Webbe H.L., Coleman R.E. (2010), Bisphosphonates and RANK ligand inhibitors for the treatment and prevention of metastatic bone disease. Eur J of Cancer, 46: 1211-1222.

8. Poršová M., Porš J., Kolombo I., Pabišta R. (2007), Současná léčba kostních metastáz. Urolog. pro Praxi, (8) 6: 272-280.

9. Pour L., Adam Z., Hájek R. (2007), Možnosti podávání bisfosfonátů u pacientů s mnohočetným myelomem. Farmakoterapie, (3) 5: 488-494.

10. Saad F. (2004), Preventing bone complications in patients with prostate cancer: The emerging role of zoledronic acid. Eur Urol suppl, (3) 5: 25-33.

11. Tesař V., Tesařová P. (2008), Nefrotoxicita bisfosfonátů u onkologických pacientů. Farmakoterapie, (4) 5: 553-560. 12.Vít V. (2009), Možnosti léčby kostního postižení u karcinomu prostaty. Urol List; (7) 4:27-29.

Submitted: 28.04 .2015

Accepted: 16.10 .2015 